\title{
Feminist Criticism in Virginia Woolf's To the Lighthouse and Ibrahim Ahmed's Janî Gel
}

\author{
Diyar Mohammed \\ The School of Foreign Languages, Final International University \\ Girne, North Cyprus \\ Email: diyar.mohammed@ final.edu.tr
}

Received: 9/6/2021 Accepted: 10/18/2021 Published:10/25/2021

\begin{abstract}
This paper investigates the concepts of Feminism and Feminist Criticisms to identify their features in two novels; Virginia Woolf's To the Lighthouse and Ibrahim Ahmed's Janî Gel. The theoretical and historical backgrounds of Feminism and the other Feminist Criticisms are presented according to their importance. The paper then introduces the two novels by presenting their plot summary. This paper tries to answer how two prominent writers, one British and one Kurdish, discuss women issues. The author wants to investigate whether both writers' cultural upbringing and social background affect the way they present women in their respective novels. Through quotations taken from the novels, one learns about the writers' ideas regarding women's issues; economic, social, psychological, and political. In conclusion, the present study argues that women's experiences in English society and Kurdish society have many similarities; however, despite the many similarities, there lay differences regarding the attitudes of both writers towards women issues and representation. For instance, Wood presents an ideal female character to oppose women's traditional roles in society in her novel. On the other hand, Ahmed paints vivid imagery of what women go through without solid women characters. Thus, this paper hopes to provide future students and researchers with helpful material on Feminism, Feminist Criticisms, and the analysis of both novels, especially the Kurdish one, since research is scarce on it.
\end{abstract}

Keywords: feminism, feminist criticisms, Janî Gel, society, To the Lighthouse

Cite as: Mohammed, D. (2021). Feminist Criticism in Virginia Woolf's To the Lighthouse and Ibrahim Ahmed's Janî Gel. Arab World English Journal for Translation \& Literary Studies 5 (4) 140-152. DOI: http://dx.doi.org/10.24093/awejtls/vol5no4.10 


\section{Introduction}

Throughout much of history, men have asserted their power over everything around them, from weaker men, women, to animals. There have been times when women were more influential in society than men; however, this was rare, as explained later in this paper. Patriarchy, the rule of men, dominates the world even today. Unfortunately, many women are affected by the teachings of patriarchy, and they conform and embolden those ideas. For instance, women have been programmed to look specific ways and do certain things to fit the definition of "woman". Many women follow the beauty standards set for them or the standards for how they should speak.

Furthermore, many women kowtow to their roles in society, like being housewives or mothers. According to Galt and Abrams (2011), feminists have been fighting against the stereotypes for men and women as they feel they are incorrect. For instance, the feminists argue why men should get all the words that show them in a dominant and sane light while women are described as weak and incompetent. Galt and Abrams state that the feminist groups argue that just because a man is powerful does not make all men inherently powerful. For them, attributes given to men and women are socially constructed, and it has nothing to do with biology. Thus, people must stop stereotyping men and women from birth and become who they want to be.

This article analyses two novels: Virginia Woolf's To the Lighthouse and Ibrahim Ahmed's Janî Gel. Woolf was one of the seminal British female writers whose voice against patriarchy was very effective. Ibrahim Ahmed was a Kurdish writer and political activist. His themes of writing stemmed from the troubled Kurdish society in the North of Iraq. According to Kamal Fuad, a Kurdish writer who wrote the preface of Janî Gel, Ahmed is considered the father of Literary Realism in Kurdish Literature (Ahmed, 2002). The readers are introduced to feminism from different perspectives and how they are shown in the two novels. This paper's author believes in the importance of studying Kurdish writings to see how women's issues are presented and how women are portrayed in general. This belief stems from the necessity for having an open debate about women's situation in the North of Iraq. The Kurdish novel is compared to an English novel to understand better the different paths each writer takes in discussing female issues.

\section{Literature Review \\ Feminism as a Term}

The first recorded time that the word 'feminism' was used goes back to the medical field. Freedman (2001) has stated that in 1871 in France, as mentioned in a medical journal, some male patients suffered from having female characteristics and shrinking sexual organs. This condition was labelled as the 'feminization' of their bodies. In his 1872 pamphlet l'hommefemme, Alexandre Dumas used the term when he talked about women acting like men doing adultery. It was not only after the sixties and seventies that the term feminist or feminism was used to label women's rights activists and movements.

\section{Historical Context}

History is rich with brave female voices who went against tyranny and patriarchy. Feminists have been very loud to let men know how they feel about the systems put forth throughout the world. The systems that are in place in many countries around the world still see women as secondary citizens. When women's issues are discussed in patriarchal societies, they

Arab World English Journal for Translation \& Literary Studies 141

ISSN: 2550-1542 | www.awej-tls.org 
are presented as a separate matter as alien to human issues. For instance, during elections in Iraq, the political parties brag about how they employ women candidates or how they intend to improve women's lives. These efforts to earn bragging rights at the expense of women's rights show how women are seen as a tool for men to earn more power in society. In academia, feminist movements are classified as waves; however, these waves are not inclusive enough. Schuster (2017) asserts that many authors reject the idea of feminist waves as, "'new feminisms' do not fit definitions of waves because of their heterogeneity ... and overstate conflicts between feminist perspectives" ( $p$. 648).

Habib (2006) mentions several prominent female thought leaders who swam against the brutal tide of patriarchy and left their mark. In the Middle Ages in Europe, women were suffering a lot as they did not have many choices other than being like properties of men. Also, women did not have support during their pregnancies and were forced to have as many children as men wanted. Among all the cruelties, one voice was heard loud and clear; Christine de Pisan. According to Habib, de Pisan was a brilliant Italian poet who argued that women should not be seen as men's property. She advocated for the creation of a community exclusively for women to express themselves creatively. Due to women's devastating state under patriarchy, de Pisan's arguments did not immediately impact; however, she paved the way for future feminists. Other parts of Europe like France and England were not without brave female voices who demanded justice for women. For instance, in France, a female writer named Madeleine Des Roches came into feminism. She was influenced by the renaissance that started in Italy. Most importantly, she was heavily influenced by de Pisan and demanded the creation of the community that de Pisan wanted.

Aphra Behn is one of the most influential women writers who emerged in England in the seventeenth century. She was a brilliant playwright whose writing themes addressed discrimination against women and how oppressed women were at that time. According to Stodard (2017), Behn did not only influence her contemporaries; she even influences writers of today, "Behn has impressed and inspired modern scholars, writers, and theatre practitioners, who have viewed her life and works as relevant antecedents to the struggles of women in their own time" (p. 6). Mary Wollstonecraft is another seminal English voice in the fight for equality for women. She was an outspoken feminist who strived for the right to education for women. Todd (2019) argues that although Wollstonecraft's demands were not new, the fearlessness of her arguments made her the spearhead of women's rights that she is known for today.

Standing on the shoulders of giant female authors and activists, four waves of feminism became a reality. These waves of feminism are significant in the history of women's rights movements as they created tangible change in the west. Andersen (2018) states that the first wave of feminism was influenced by Mary Wollstonecraft' book titled A Vindication of the Rights of Women as it ignited debates and led to women finally getting organized to earning their rights. Anderson says that women of this wave fought to get political rights just like men enjoyed as they saw this right to be of utmost importance in ending gender discrimination. Hence, the women's movement at this time is known as the suffragists' movement. The suffragists asked for the right of voting; they believed that through voting rights, women's voices could be heard. Although the first-wave feminists asked for sweeping change, the movement lacked race, class, and language 
diversity. The movement lit a candle for other feminist movements around the world; however, at that time, the movement was exclusive to white women.

Emboldened by the rights they had gained through the first wave, women started asking for more fair rights and freedoms. Although the second wave of feminism's beginning is traced back to the sixties, the movement was heavily influenced by Simone de Beauvoir's work titled The Second Sex, which was published in 1948. According to Rampton (2015), second-wave feminists were radical in their demands and ideas, and they have started to differentiate between the terms sex and gender. They went against the objectification of women, which stemmed from venues like beauty pageants. Rampton claims that one of the significant differences that distinguish the second wave of feminism is that it was inclusive; women of colour and around the world with different classes and backgrounds could be heard. Gender issues were not the only concern here, as demanding legal, political, and economic rights were further emphasized.

\section{Feminist Theories}

Feminists identify with different ideas and theories; one cannot just call one a feminist and leave it there. Mackay (2015) asserts that the labels used by feminists are not so prominent nowadays as it was when the second wave of feminism started. However, it will be helpful for the readers to get to know some of the feminist theories that have impacted the women's movement until today, and they will be shortly explained in the following paragraphs.

\section{Liberal Feminists}

As the name suggests, they concern themselves with getting women the freedom to do and practice what they want without any pressure from men. They want women to be free to choose any religion, career, or political alliance they desire. Mary Wollstonecraft's and John Stuart Mill's thoughts are regarded as the cornerstone for liberal feminists. Priyadharshini, Mohan, Hariharasudan, and Sangeetha (2021) assert that Mill asked for the emancipation of women in his writings and that men held women back through the labels they imposed on women, like women being weak. Mill says that "the subordination of women, which deprives them of freedom, is an unjust violation of the principle of liberty" (as cited in Priyadharshini et al., 2021, p. 47). Since the slogans of liberal feminists argue for freedom, they resonate with ordinary people.

\section{Marxist and Socialist Feminisms}

According to Gordon (2016), Marxist feminists see capitalism as the root of the discrimination against women. On the other hand, socialist feminists, although they agree that capitalism hinders societies, argue that men from the middle or lower classes contribute to the discrimination of women. Furthermore, socialist feminists pointed out that the oppression of women is not only done by white men or just high-class men, for race and class were not vital determiners. This idea of holding men from different walks of life responsible is vital for social feminists as there would be tangible culprits, not just an abstract idea like capitalism. Gordon says the concept of expanding the Marxist idea of discrimination to include poor men came from Patricia Mainardi' work titled The Politics of Housework. Marxist and Social feminists ask women to first revolt against capitalism then against patriarchy as for them, they both contribute equally to discrimination against women. 


\section{Radical Feminism}

According to Tong and Botts (2018), radical feminists ask for sweeping change worldwide as they see the struggles women face to be similar to an extent. Radical feminists reject the notions that women must follow what men say or control women's reproduction rights. Shulamith Firestone is considered the spearhead of radical feminism. In 1970 she published her outstanding work The Dialectic of Sex, in which she calls on women to set themselves free from the shackles of motherhood. Other feminists like Mary Daly ask women to be free from religion. Hence, radical feminism is a movement for the emancipation of women from everything imposed on them.

\section{Psychoanalytic Feminism}

According to Schanoes (2016), psychoanalytic feminism stems from the writings of Dorothy Dinnerstein and Nancy Chodorow, who dived deep into explaining what differentiates the psyche of a woman from that of a man. Schanoes says that Dinnerstein and Chodorow investigated the relationship between boys and their fathers and how the fathers nurture the boys to be challenging and competitive. On the other hand, the mothers prevent the girls from acting tough or challenging the boys and teach the girls to act 'girly'. Chodorow provides a solution for this discrepancy in parenting and says Dual-parenting prevents it. Dual-parenting is when both parents raise the children without separating them into circles of toughness and softness.

Tong and Botts (2018) say psychoanalytic feminists use Freud's and Lacan' ideas to explain why children become males and females. For psychoanalytic feminists, discrimination starts from birth as girls would be raised to think like women and act feminine; hence their psyche gets used to this idea. Tong and Botts assert that different upbringing affects the children's psyche; for instance, if patriarchy does not impose masculinity and femininity, then the children's experiences would be different. Psychoanalytic feminists argue that the world must change its ways of viewing genders and stop labelling them with outdated words so that people can choose whom they want to be by themselves.

\section{Postmodern Feminism}

Postmodern Feminism is concerned with dismantling the idea that everything must be binary, like female/male or day/night. Tong and Botts (2018) say that Hélène Cixous is one of the seminal faces of postmodern feminism who rejected the binary system set in tradition. The binary system labelled men as vital, which made women labelled weak; this was unacceptable for Cixous as it created discrimination against women. Cixous claimed men had established themselves as the self, which made women be the other and thus, women became unthought of or just an afterthought. Cixous demanded more from women writers as they "can lead the Western world out of the dichotomous conceptual order that causes it to think, speak, and act in terms of someone who is dominant and someone else who is submissive" (p. 293).

\section{Feminist Criticism}

The word 'criticism' brings negative connotations to some peoples' minds, making them feel insecure. Kaplan (2020) asserts that feminist criticism started when woman readers started to evaluate women's writings by themselves instead of reading men's interpretation of those writings. This act by women readers was revolutionary as they decided to become active rather than passive like always; however, it did not stop at that. Feminist criticism was expanded to include any writing 
that deals with gender and women issues. Fard (2016) says that feminist criticism is "concerned with the impact of gender on writing and reading" (p. 336); hence, this paper investigates not only a novel by a woman but one by a man, too. Feminist criticism did not act as a regulated and organized entity until the twentieth century when women rose against patriarchy. From then on, feminist critics have many objectives they want to achieve. The first objective is to rewrite the literary history to cite the works of women, which were overshadowed and overlooked by male historians. Secondly, the language of literary works creates problems for women. As feminist critics argue, the language used in writing literature is demeaning to women and gender-biased against women; thus, they ask to create a language exclusive to women while others ask to modify the current language. Thirdly, they want to help women learn how to read literature. As mentioned earlier, women did conform to society's patriarchal rules and norms, consciously or subconsciously. Hence, the men-biased language in literature helped further implement the dominant ideas of men in the minds of women readers. So feminist critics want to create a woman reader who does not accept everything she reads as the absolute truth. They want to guide women to be critical readers who reject the negative depictions and narratives about them. Last but not least, they undertake the responsibility to redefine what a well-written piece of literature is. They question the accepted significant works of literature and try to re-order their value.

\section{Plot Summary of To the Lighthouse}

The Window: Just before World War I on the Isle of Skye vacates The Ramsays in their summer residence. The Ramsays consist of Mr Ramsay, Mrs Ramsay and their eight children James, Andrew, Jasper, Roger, Prue, Rose, Nancy and Cam. Several guests and visitors are in their house like Lily Briscoe, Charles Tansley, William Bankes, Paul Rayley, Minta Doyle and Augustus Charmichael. James, Ramsays' youngest child, pleads with her mother to take him to the lighthouse; she agrees if the weather gets better. However, Mr Ramsay tells them the weather will not get better, so they cannot go. James resents his father more because of this and thinks he is stealing Mrs Ramsay's affection from him. After that, while Mrs Ramsay is reading for James, Lily watches them and starts drawing a painting of her in the afternoon. Also, Mr Ramsay watches his wife and thinks of his flaws and panics about the idea of not fulfilling his greatness. At that time, Paul and Minta become engaged after Paul proposes while taking a walk with Andrew and Nancy. In the evening there is a big dinner for fifteen people. It does not start well; however, it ends well as all guests feel satisfied, which results in Mrs Ramsay being thrilled (Woolf, 1930).

Time Passes: Ten years pass, and the summer house is neglected and suffers from the wrecks of abandonment. Mrs Ramsay dies, leaving the family unexpectedly. Andrew dies in the war, and Prue dies while giving birth. The family's life is full of gloom. The remaining Ramsays decide to go back to their summer house, and they let Mrs McNab, a housekeeper, know about it so she can tidy up the house. She does her job and restores the house to its previous state, so the Ramsays spent their time well.

The Lighthouse: All of the Ramsays, except for the deceased Mrs Ramsay, Andrew and Prue, return to their summer residence accompanied by guests, including Lily. This time $\mathrm{Mr}$ Ramsay is the one who initiates the idea of visiting the lighthouse. In the morning, Mr Ramsay, Cam and James are set to visit the lighthouse. Mr Ramsay gets angry as the trip does not set off on time. He seeks affection from Lily; however, she cannot provide him with any. At last, their 
journey sets off, and Lily remains in the house finishing the painting she started ten years ago of the late Mrs Ramsay. On the journey, Cam and James feel disgusted about their father's constant need for affection. However, they form a bond with him, especially James, whose skills as a sailor are praised. At the summer residence, Lily finishes her long-awaited painting and puts her brushes down.

\section{Plot Summary of Janî Gel}

Ciwamêr is a young Kurdish man who has a young and beautiful wife named Kalê. He works hard to provide for his family and has nothing to do with politics. His wife is pregnant, and she is in labour. She is in great agony with no professional help. Ciwamêr decides to go himself to bring a midwife to help her with childbirth. On that day, there was a big protest held by the Kurdish Liberation Army against the Iraqi government. Ciwamêr tries his best to avoid the protest, but he fails. After the Iraqi police and army disrupted the protest, people ran away for their lives. By chance and mistake, Ciwamêr becomes the lead runner in front of the protestors. The army fires random bullets towards them, and he gets injured. Later, he gets arrested and judged to ten years of imprisonment for he is thought to be the leader of the protestors. These are all Ciwamêr's reminiscences as his story commences when he gets free (Ahmed, 2002).

While in prison, Ciwamêr is told by his cousin Lawê that Kalê had given birth to a son they named Hiwa (hope), and they are doing well living in Lawê's house. Driven by the hope of seeing his wife and son, Ciwamêr immediately starts searching for them after getting free. He goes back to his city and straight to Lawê's house. Lawê tells him that Kalê and Hiwa are not there; they went to their village. Ciwamêr gets angry and decides to go and bring them back. However, Lawê tells him that it is too dangerous to go and promises to send someone after them soon. Ciwamêr accepts and wanders around his city; he cannot recognize it. The government completely demolished his house. His friends were either arrested or working for the government, and some of them joined the Kurdish Liberation Army, and very few of them had regular jobs. After a while, he meets with some old and new friends in a house. They all want to know about his heroics that led to his imprisonment. He tells them the truth that he did nothing heroic. He then tells them about life in prison and how the authorities treated him like an animal and tried to make him sign papers, which made him confess to being a rebel leader.

Getting frustrated with Lawê, Ciwamêr decides to go and bring his wife and child back himself. This task is dangerous for everybody as once one gets out of the city towards the villages, one will be prosecuted as a member of the Kurdish Liberation Army. It is even double-dangerous for Ciwamêr as he must inform the authorities whenever he tries to change his location. On his way, he encounters a woman and her child in an abandoned village. The Kurdish Liberation Army arrested her husband on account of helping the Iraqi government. After a few moments, some helicopters fly by; they run and hide. However, the woman runs back to her place to save the money she has inside her little shop. While she tries to take the money, the helicopters start bombarding the place; the woman and the baby die.

After that incident, Ciwamêr goes on his way, but he soon gets arrested by the Kurdish Liberation Army. They suspect him of being a spy for the Iraqi government, so they beat and hurt him. They take him to their leader; Ciwamêr introduces himself, and the leader recognizes him as 
one of the imprisoned heroes from ten years ago. Ciwamêr does not correct the leader's account as he corrected his friends about his fake heroism. So, the leader apologizes to him and gives him food and new clothes. However, when the leader knows about the reason for Ciwamêr to be in those forsaken locations, he has terrible news for him; the village Ciwamêr is trying to travel to was destroyed, and bombs killed everyone brutally. After hearing the devastating news, he goes back to his city. Heartbroken, Ciwamêr decides to sell the remains of his house. He then joins the Kurdish Liberation Army to achieve 'giving birth to a free nation'. In the end, after some time while on duty, he gets a letter from Lawê. In the letter, he finds out that his wife had died ten years ago while in labour. Lawê fabricated the story that she gave birth to a son so that Ciwamêr does not give up on life.

\section{Discussion}

\section{Women as Wives and Mothers}

Being wives and mothers are deemed the most natural roles of women in society. Thus, Woolf places great emphasis on these two roles to show that they are not so natural and, in many cases, damaging the women. Mrs Ramsay is a beautiful middle-aged woman. She is the typical Victorian wife and mother with all the attributes that a patriarchal society asks for in a woman. Mrs Ramsay is kind, loving, domestic, and very supportive of her husband and her only concern is to please everybody. She fulfils all her predetermined gender roles perfectly. However, she dies in the second part of the novel, leaving a significant gap in her husband's life. Mrs Ramsay is a depiction of Woolf's mother. She plays many roles in the novel, and all of those roles are highly dominated by patriarchal rulings. She is the loving mother of her children, her husband's supportive wife, and the meddler for her guests' affairs.

In a conversation between Mrs Ramsay and her son James, Mrs Ramsay says, "Yes, of course, if it's fine tomorrow," said Mrs Ramsay. "But you'll have to keep up with the lark," she added" (Woolf, 1930, p. 1). Her son wants to go to the lighthouse, and she agrees to take him should the weather be fine; "But...it will not be fine." (p. 1), this is Mr Ramsay's response to her remarks. He disagrees with her and says that the weather would not be fine, meaning they cannot go to the lighthouse. "But it may be fine-I expect it will be fine," said Mrs. Ramsay, making some little twist of the reddish-brown stocking she was knitting, impatiently." (p. 1); Mrs Ramsay very politely counters her husband's words. In these exchanges, one sees that Mrs Ramsay desperately tries to retain a balance between her obligations, respecting her husband's will and fulfilling her child's dream.

Mr Ramsay is desperate for his wife's sympathy. He wants confirmation from her that his life matters. As a scientist, Mr Ramsay feels that his life revolves around scientific facts, and he is not living well. As powerful as he is, he lacks sympathy; he needs it to be assured of himself. Mrs Ramsay tries her best to raise his self-confidence. She tries to remind him how their guest, Tansley, considers him the best in his field. However, this is not enough for his ego; he does not need confirmation from a man. The reader may notice that his refusal of men's sympathy is that he feels all men lack the kindness and love of women; this feeling is due to the patriarchal mindset engraved in him. Men are interested in science, knowledge, work and tangible things; the abstract part of life is connected to women; this is why Mr Ramsay turns to his wife for sympathy rather than to 
his male companions. Also, for the same reason of society's rules, Mrs Ramsay feels obliged to deliver what she is asked from by her husband (Shumeyko, 2008).

In her mind, Mrs Ramsay does not wish for her children to grow up, especially James as "she thought, he will never be so happy again, but stopped herself, remembering how it angered her husband that she should say that" (Woolf, 1930, p. 49). She is unhappy with the thought that her children will eventually grow up. As a mother, her primary role is to take care of her children. The Children occupy a great deal of her life. When they grow up, her life will be meaningless. She does not want her kids to grow up and lose their innocence. Just like how her husband finds happiness from her sympathy, she finds happiness from her children's innocence. They are her escape from the demanding world of adults. Finally, the reader learns how submissive Mrs Ramsey is; she does not express her feelings in front of her husband again. She knows her thoughts make her husband angry, so she keeps them for herself. Mrs Ramsay is the embodiment of Angel in the House. The Angel in the House, in the words of Woolf, was "intensely sympathetic...immensely charming...utterly unselfish...excelled in the difficult arts of family life...sacrificed herself daily...never had a mind or a wish of her own" (Woolf, 1942, p. 2).

In Janî Gel, Kalê is a young and lovely woman character in the novel. She is the wife of the protagonist, Ciwamêr. When the novel commences, she is already dead. The things she does or say take place only in Ciwamêr's reminiscences. In his first rumination, Kalê is pregnant and is in labour with no professional help. A midwife is her only hope. When Ciwamêr goes out to bring a midwife, he gets caught in the middle of a protest and gets imprisoned for ten years. Moreover, at the end of the novel, the reader learns that Kalê died while in labour. Though very much loved and revered by her husband, it seems like her only two roles are as a wife and mother "a young woman was lying on the floor, the stream of pain (labour) made her glowing face turn frown" (Ahmed, 2002, p. 11).

Ciwamêr is having a reminiscence of Kalê's pregnancy. The reader may get the idea that women's sole role is to be mothers, which might be the society's wrong idea that Ahmed wanted to convey as the first mention of a woman is a pregnant one. Kalê's labour makes her helpless. She is defined by her pregnancy as if her existence is unimportant. Also, in her exchanges with her husband, it seems like she is already conformed to her role;

Ciwamêr: Really, this labour is reckless and nonsense! Oh God, what is the meaning of this torture? Kalê: No, please darling, do not say such things. How can you say that? Do not let sympathy blind you; conceiving a human being deserves much more labour than this! (p. 13).

Women in patriarchal societies conform to their duties. They are ready to defend those roles and endure as much pain as possible for them. Here, pregnancy and labour can be viewed as an example of burdens forced on women and Kalê's defence as women's inferior mentality, which accepted her reality under patriarchy. 


\section{Marriage}

The institution of marriage is held high in To the Lighthouse; it depicts a Victorian society that revered marriage. Mrs Ramsay keeps glorifying marriage throughout the novel. Moreover, as a married woman, her role is magnified; Woolf gave her character great importance in the novel. Y1ldiz (2013) asserts that Woolf's attitude towards the character of Mrs Ramsay should not be taken literally; the glorification of her role is not to say that what she does or say is essential and proper; instead, she wants to mock her way of thinking. She tries to show and ridicule her seriousness towards what society has imposed on her. For Woolf, it is shameful that Mrs Ramsay is in a submissive marriage and tries to arrange other marriages between the other characters. The sound reasoning for Woolf's ideas is Lily's thoughts about marriage. Through Lily's character, Woolf conveys her ideas about marriage.

Mrs Ramsay says, "she must, Minta must, they all must marry...there could be no disputing this...an unmarried woman has missed the best of life" (Woolf, 1930, pp. 41, 42); here one understands what Mrs Ramsay thinks about marriage. She believes that every girl should get married. She advocates for her child, Minta, to get married so she can have a happy life. She also thinks that Lily should get married as none of her achievements are of any value to her. Mrs Ramsay believes that the only true happiness comes after the girl gets married. This view, Yildiz declares, is traditional; a girl's existence has value only when connected to a man; other than that, she has no value in the world. This view is also ironic, as Mrs Ramsay's marriage is not very happy. She is constantly struggling to fulfil her husband's and children's needs, leading to a loss of her own identity in the process. However, her perspective might be understandable looking at the rules of the society imposed from childhood. Shihada (2005) states an interesting point that is; Mrs Ramsay has a mania about marriage. She is obsessed with arranging marriages between the singles.

Woolf presents another perspective on marriage through Lily's thoughts. Lily tries her best to emancipate herself from the conventions of society. She is the new woman that Woolf wants to introduce; her views are progressive and radical to her society. Lily perceives $\mathrm{Mr}$ and $\mathrm{Mrs}$ Ramsay's relationship as a typical example of marriage, "So that is marriage, Lily thought, a man and a woman looking at a girl throwing a Ball" (Woolf, 1930, p. 42). She looks at them curiously, as if she tries to understand the meaning of marriage that Mrs Ramsay so passionately advocates.

In Janî Gel, Ciwamêr has a long reminiscence about the first time he met Kalê and how they got married. This time the reader sees that as a young girl, Kalê's duty was to get married "it was only two years ago when Kerimbeg proposed a marriage between you and his son" (Ahmed, 2002, p. 51). This exchange is between Kalê and her mother in Jwamêr's reminiscence. Her mother reminded her of when a proposal was made to Kalê and refused by her father. She was only fourteen or fifteen years old at the time of that proposal. Hence, the reader can observe that a girl is not expected to finish school, get a job or anything. When men feel that the girls are eligible for marriage, they propose. Furthermore, her father's refusal was not based on his daughter's young age; her father refused due to his disagreement with the boy's father.

Arab World English Journal for Translation \& Literary Studies 


\section{The Domestic Role of Women}

The Ramsays have many guests. As a woman, Mrs Ramsay feels an obligation towards her guests' happiness, as this obligation is predetermined by society for women. Shihada (2005) asserts that Mrs Ramsay has the skill to make her male guests feel comfortable. She can improve her husband's self-confidence; this is also correct with her male guests, "Charles Tansley revived....she made him feel better pleased with himself than he had done yet, and he would have liked, had they taken a cab, for example, to have paid the fare" (Woolf, 1930, p. 9). This interaction happens between Mrs Ramsay and Tansley. When all the members of the house go out, she feels that Tansley is depressed. She feels an instant sense of duty to make him feel better. Mrs Ramsay asks him if they can go out to the market. On their way, she starts narrating some stories about her husband; she tells him how her husband had misfortunate incidents in his life, which makes Tansley feel better. She also feels sympathy towards another of the guests, Mr Bankes. She feels that he is not content with his life; she previously tried to arrange a marriage for him. This sense of responsibility comes from the ideas imposed on her by the patriarchy.

Mrs Ramsay's domestic role is exemplified by organizing a big dinner for her family and their guests, "But what have I done with my life? thought Mrs Ramsay, taking her place at the head of the table...William, sit by me" (p. 70). This event has a significant value in the novel. It is a dinner held by Mrs Ramsay at their house. She guides each member to their designated seat; this shows the role of Mrs Ramsay around the house works. Mr Ramsay's voice cannot be heard here; it means that it is not men's duty to take care of any work around the house. By focusing on the guests' seats, Woolf shows the triviality of women's works. It involves no brain work, which is why Mr Ramsay, as a man, has no interest in organizing the dinner.

In Janî Gel, after girls get married and fulfil their predetermined role, they face another role; taking care of their houses, "Ciwamêr said: No, sister, it is not necessary to wake him, bring us whatever you have so we will eat and go" (Ahmed, 2002, p. 132). This exchange is between the wife of Kawa, who is one of Ciwamêr's friends, and Ciwamêr himself. Here the reader witnesses that the woman is responsible for taking care of her husband's guests. She does what her husband has told her. The husband is not expected to do anything around the house, even when he has guests.

As said before, men are responsible for working outside the house to provide for their families. In Kurdish society's case, many women became widows, or the government imprisoned their husbands. Thus, many women were obliged to move back to their parents' or relatives' houses to survive. "His cousin Lawê wrote to him that he took his (Ciwamêr's) wife and son to his (Lawê's) house and gave them a basement and rented his house (Ciwamer's) for them" (p. 23). Hence one sees that a woman should be taken care of, if not by her husband, then by a close relative.

\section{Conclusion}

The present paper aimed to explore and examine the different concepts of Feminist Criticisms and relate those concepts to two different novels; the first novel was Virginia Woolf's To the Lighthouse, and the other was Ibrahim Ahmed's Janî Gel. The paper has identified

Arab World English Journal for Translation \& Literary Studies 
some forms of Radical Feminism, Marxist and Socialist Feminism, Liberal Feminism, Psychoanalytic Feminism, and Postmodern Feminism in the two novels.

There is a similarity between the two novels on the portrayal of male economic domination. Both novels present typical women as examples of female economic subordination; women are prevented from the rights of work outside the house. However, the two novels differ from the perspective of offering a solution. Woolf offers an exceptional and ideal female, Lily, as a solution and role model for women to follow; however, Ahmed only offers facts of why and how women are dominated and encourage them to emancipate themselves economically, so they get their freedom. The two novels have some similarities. Both of them display how marriage institution is imprisonment for women and how the socially-constructed prejudices against women have become the rhetoric. In regards to politics, there is a difference between the attitudes of the two writers. Woolf does not present the reader with much detail about the differences between males and females in politics, whereas Ahmed displays the political domination of males over females in great detail.

\begin{abstract}
About the Author:
Diyar Jamal Mohammed is an Assistant Lecturer from Sulaymaniyah, Iraq. His Master's Degree is in English Literature from Cyprus International University, North Cyprus (2016). As of 2019, he is a PhD candidate in English Language Teaching at Cyprus International University. His current research interests focus on literary criticism and language teaching methods. ORCiD ID https://orcid.org/0000-0002-4123-4319
\end{abstract}

\title{
References
}

Ahmed, I. (2002). Janî Gel (2 $2^{\text {nd }}$ ed.).

Andersen, C. (2018). Getting to the root of\# metoo-through the fourth wave of feminism (Master's thesis). University of Copenhagen, Copenhagen, Denmark.

Fard, S. F. (2016). A Short Introduction to Literary Criticism. International Journal of Humanities and Cultural Studies (IJHCS) ISSN 2356-5926, 328-337.

Freedman, J. (2001). Concepts in the social sciences: Feminism. Open University Press, Philadelphia.

Galt, H. G., \& Abrams, M. H. (2011). Glossary of Literary Terms (11th ed.). Cengage learning.

Gordon, L. (2016). 'Intersectionality', Socialist Feminism and Contemporary Activism: Musings by a Second-Wave Socialist Feminist.Gender \& History, 28(2), 340- 357. https://doi.org/10.1111/1468-0424.12211

Habib, M. A. R. (2008). A history of literary criticism: from Plato to the present. John Wiley \& Sons. ISBN: 978-1-405-14884-9

Kaplan, S. J. (2020). Varieties of feminist criticism. In Making a Difference: (pp. 37-58). Routledge. ISBN 9780415010115

Mackay, F. (2015). Radical feminism. Theory, Culture \& Society, 32(7-8), 332-336. https://doi.org/10.1177/0263276415616682

Priyadharshini, P., Mohan, S., Hariharasudan, A., \& Sangeetha, J. (2021). Authenticity of liberal feminism in Namita Gokhale's texts. Linguistics and Culture Review, 5(S1), 46-59. https://doi.org/10.37028/lingcure.v5nS1.1312

Rampton, M. (2015). Four waves of feminism. Pacific University Oregon. 
Schanoes, V. L. (2016). Fairy tales, myth, and psychoanalytic theory: Feminism and retelling the tale. Routledge. https://doi.org/10.4324/9781315581859

Schuster, J. (2017). Why the personal remained political: comparing second and third wave perspectives on everyday feminism. Social Movement Studies, 16(6), 647-659. https://doi.org/10.1080/14742837.2017.1285223

Shihada, I. M. (2005). A Feminist Perspective of Virginia Woolf's Selected Novels' Mrs Dalloway'and' To the Lighthouse'. Al-Aqsa University.

Shumeyko, A. M. (2008). Gender within Stream of Consciousness: To the Lighthouse and the Sound and the Fury, (Unpublished Senior Thesis). Boston: Boston College.

Stodard, N. E. (2017). Aphra Behn on the Contemporary American Stage: Behn's Feminist Legacy and Woman-Directed Revivals of The Rover. University of South Florida.

Todd, J. (2019). The first life of Mary Wollstonecraft: Godwin's perplexing Memoirs. Journal of Gender Studies, 28(7), 759-765. https://doi.org/10.1080/09589236.2019.1660152

Tong, R., \& Botts, T. F. (2018). Feminist thought: A more comprehensive introduction. Routledge. https://doi.org/10.4324/9780429493836

Woolf, V. (1930). To the Lighthouse-Virginia Woolf. feedbooks. https://gutenberg.net.au/ebooks01/0100101h.html

Woolf, V. (1942). Professions for Women. "The Death of the Moth and Other Essays". https://gutenberg.net.au/ebooks12/1203811h.html

Yıldız, F. (2013). Women Types in To the Lighthouse and Mrs. Daloway. Afyon Kocatepe University Journal of Social Sciences, 15(2), 17-24. https://doi.org/10.5578/JSS.6619 